\section{References}

1. G. Kurdjumow and G. Sachs: Über den Mechanismus der Stahlhärtung. Ztsch. Phys. (1930) 64, 325343.

2. G. Wassermann: Über den Mechanismus der $\alpha \rightarrow \gamma$ Umwandlung des Eisens. Mit. K. W. I. Eisenforsch. (1935) 17, 149-155.

3. Z. Nishiyama: X-ray Investigation of the Mechanism of the Transformation from Face-Centered Cubic Lattice to Body-Centered Cubic. Sci. Repts. Tohoku Imp. Univ. (1934) 23, 637-664.

4. R. F. Mehl and G. Derge: Studies Upon the Widmanstätten Structure, VIII, The Gamma $\rightarrow$ Alpha Transformation in Iron-Nickel Alloys. Trans. AIME (1937) 125, 482-496.

5. A. B. Greninger and A. R. Troiano: Kinetics of the Austenite $\rightarrow$ Martensite Transformation in Steel. Trans. Amer. Soc. for Metals (1940) 28, 537-562.
6. A. B. Greninger: The Martensite Transformation in Beta CopperAluminum Alloys. Trans. AIME (1939) 133, 204-221.

7. G. Sachs: Allgemeine Gesetzmässigkeiten der Gefüge-und Eigenschaftsänderungen bei Umwandlungsvorgängen. Ztsch. f. Metallkunde (1932) 24, 241-247.

8. R. Mehl, C. Barrett, and D. Smith: Studies upon the Widmanstätten Structure, IV, The Iron-Carbon Alloys. Trans. AIME (1933) 105, 215-249.

9. A. B. Greninger and A. R. Troiano: Crystallography of Austenite Decomposition. AIME Metals Tech., Aug. 1940.

10. A. B. Greninger and V. G. Mooradian: Strain Transformation in Metastable Beta Copper-Zinc and Beta Copper-Tin Alloys. Trans. AIME (1938) 128, 337-355.

11. G. Phragmén: Austenitsönderfallet och martensitomvandlingarna ur termodynamisk synpunkt. Särtryck ur Teknisk Tidskrift (1938) 23, 1-12.
12. A. B. Greninger: A Back-Reflection Laue Method for Determining Crystal Orientation. Trans. AIME (1935) 117, 61-74; Ztsch. f. Kristallog. (1935) 91-A, 424-432.

13. W. A. Wooster: A Text-book on Crystal Physics. Cambridge Univ. Press, London, 1938.

14. C. H. Mathewson and G. H. Edmunds: The Neumann Bands in Ferrite. Trans. AIME (1928) 80 , 311-333.

15. A. B. Greninger: Transformation Twinning of Alpha Iron. Trans. AIME (1936) 120, 293-303.

16. G. Hägg: X-ray Investigation on the Structure and Decomposition of Martensite. Jnl. Iron and Steel Inst. (1934) 130, 439-451.

17. K. Honda and $Z$. Nishiyama: On the Nature of the Tetragonal and Cubic Martensites. Sci. Repts. Tohoku Imp. Univ. (1932) 21, 299-331.

18. H. Esser, W. Eilender, and K. Bungardt: Röntgenographische Untersuchungen von Metallen bei hohen Temperaturen. Archiv Eisenhüttenwessen (1938) 12, 157-161.

\title{
Effeet of Composition on the Wire Textures of Copper and Its Solid Solution Alloys
}

\section{WALTER R. HIBBARD, Jr., Junior Member AIME}

It has been proposed ${ }^{1}$ on the basis of slip and flow that the ideal deformation texture of drawn wire for facecentered cubic metals is a (111) direction parallel to the wire axis. Under these considerations, an intermediate [100] texture is permissible but should eventually change to the stable [111] orientation. This theory does not explain why copper and its alloys containing up to about 30 pet nickel, 5 pct zinc and 1 pct, aluminum were found to have a double [111], [100] texture, while alloys with at least 8 pct zinc and 2 pct aluminum developed essentially a single [111] texture. ${ }^{1,2}$ It does suggest, however, that the [100] component of the former alloys should disappear with additional deformation. ${ }^{3}$ Some evidence exists to support this suggestion. Howald ${ }^{4}$ reported that annealed copper wire previously drawn 93.8 pct and 98.5 pct developed a single [111] texture. Since, in wire, the drawn and annealed textures are similar, these wires probably had a single [111] deformation texture before annealing. In addition, although cold rolled polycrystalline copper and $80-20$ brass were found to form different types of pole figures, ${ }^{5,6}$ single crystals of these metals when rolled from the stable (110) [112] orientation were found to produce essentially the same pole figure. $^{7,8}$ It may be, therefore, that while the addition of solute elements changes the path by which the final texture is obtained, the final texture is not changed.

\section{Experimental Results}

The wires remaining from the previous investigation ${ }^{1}$ already drawn about 50 pct reduction in diameter were further drawn to 86 pct and then to 96.4 pet total reduction in diameter. The textures were determined after these stages by transmission $\mathrm{X}$ ray photograms taken with a copper $\mathrm{K}$-alpha beam rotated $\theta$ degrees toward the wire axis. It was found that the ratio of the [111] and [100] intensities of the double texture in copper and its alloys containing 0.94 pet aluminum, 30.70 pet nickel, 2.61 pct zinc and 4.99 pct zinc increased from about 3:1 for the 50 pet reduction to about 9:1 for the 86 pct reduction. After 96.4 pct reduction, these wires exhibited essentially a single [111] texture.

\section{Summary}

Thus, the drawn wire deformation texture of copper and its alpha solid solution alloys containing aluminum,

\footnotetext{
Technical Note No. 19 E. Manuscript received May 12, 1949.

* Assistant Professor of Metallurgy at Yale University, New Haven. Conn ${ }_{1}$ References are at the end of the note.
}

nickel or zinc is essentially a single [111] texture as predicted by theoretical considerations of slip and flow. ${ }^{1}$ For copper and its alloys containing up to about 1 pet aluminum, 5 pet zinc and at least 30 pct nickel, an intermediate [100] component is found after about 50 pet reduction in diameter, but disappears after about 95 pct reduction in diameter. For alpha solid solution alloys containing at least about 2 pct aluminum and 8 pct zinc the single [111] texture is developed considerably more easily and is found after about $\mathbf{5 0}$ pct reduction in diameter. No explanation of this compositional effect is apparent. Similar work is contemplated for cold rolled and cold compressed alloys.

\section{References}

1. W. R. Hibbard, Jr. and M. K. Yen: Trans. AIME 175, 126. Metals Tech. Feb. 1948, TP 2334.

2. W. R. Hibbard, Jr. and D. E. Trout, II: Trans. AIME 185, 620. Jnl. of Metals, Sept. 1949, TN 18.

3. W. R. Hibbard, Jr.: Disc. of R. M. Brick's paper on Deformation Textures, ASM Symp. on Cold Working of Metals, Oct. 1948.

4. T. S. Howald: Disc. of Ref. 1. Trans. AIME, 175, 126. Metals Tech. Aug. 1948, TP 2449.

5. R. M. Brick, D. L. Martin and R. P. Angier: Trans. ASM (1943) 31, 675 .

6. O. Dahl and F. Pawlek: Ztsch. Metall. (1936) 28, 266.

7. C. S. Barrett and F. W. Steadman: Trans. AIME (1942) 147, 57.

8. J. E. Burke and C. S. Barrett: Trans. AIME 175, 106. Metals Tech., Feb. 1948, TP 2327. 